Jurnal Pendidikan Biologi 7 (1) (2017) $20-28$
Journal of Biology Education
$\frac{\mathrm{http} / / / \text { jurnal.unimed.ac.id/2012/index.php/JPB }}{\text { eISSN: } 2502-3810 \mathrm{pISSN}: 2086-2245}$

\title{
Pengaruh Model Pembelajaran Berbasis Proyek dalam Tatanan Group Investigation Terhadap Berpikir Tingkat Tinggi Di USI Pematangsiantar
}

\author{
Fenny Mustika Piliang* \\ Program Studi Pendidikan Biologi, Universitas Simalungun Pematangsiantar \\ *Korespondensi: feny.mustika88@gmail.com
}

\begin{abstract}
This study aims to determine the effect of Group Investigation with Project Based Learning model towards higher order thinking. The population of this research were the total, 60 under-graduated students of Simalungun University in fourth semester. They grouped as first experimental class treated by Group Investigation combine with PJBL, for next experimental class taught by Group Investigation and for control class taught by using conventional learning model. The research instrument uses a test result of learning ability of higher order thinking. This study include quasi experimental method. The data were analyzed by helping SPSS 21.0 program using F-test (ANACOVA $\alpha=5 \%$ ). The results shown that: The higher order thinking ability of under-graduated students of Simalungun University treated by Group Investigation were significantly high $(88,60 \pm$ $3,73 ; \bar{x} \pm \mathrm{SD})$ than group investigation class $(81,00 \pm 4,01(\bar{x} \pm \mathrm{SD})$ and conventional class $74,60 \pm 3,58$ $(\bar{x} \pm \mathrm{SD})$ with $\left(\mathrm{F}_{\text {hitung }}=67,742 ; \mathrm{P}=0,000\right)$. Therefore, it can be concluded that Group Investigation combinewithPJBL wereaffected thestudents'higherorderthinkingabilities.
\end{abstract}

Keyword: Group Investigation, Higher Order Thinking, Project Based Learning.

\section{PENDAHULUAN}

Kegiatan belajar mengajar adalah suatu kondisi yang kompleks yang dengan sengaja diciptakan (Dimyati dan Mudjiono 2006). Seorang pengajar harus mampu menciptakan kondisi belajar yang efektif yang didalamnya terkandung berbagai unsur yang saling mempengaruhi satu sama lain. Proses pembelajaran diharapkan dapat terlaksana melalui pengumpulan data dengan eksperimen, pengamatan dan deduksi untuk menghasilkan suatu penjelasan tentang sebuah gejala yang dapat dipercaya. Salah satu masalah yang dihadapi dunia pendidikan adalah lemahnya proses pembelajaran. Di Indonesia, pembelajaran kemampuan berpikir memiliki beberapa kendala, salah satunya adalah terlalu dominannya peran dosen sebagai sumber ilmu sehingga mahasiswa hanya diangap sebagai wadah yang akan diisi ilmu oleh dosen. Kendala lain yaitu sistem penilaian prestasi mahasiswa lebih sering didasarkan melalui tes-tes yang sifatnya menguji kemampuan kognitif tingkatrendah.

Pembelajaran yang pada umumnya dilakukan oleh dosen lebih banyak menekankan pada aspek pemahamandan 
pengetahuan sedangkan aspek menganalisis, mengevaluasi bahkan mencipta sangat jarang sekali dilakukan. Pembelajaran masih bersifat teacher-centered dan mahasiswa kurang diberi kesempatan untuk mengembangkan kemampuan berpikir tingkat tinggi. Proses pembelajaran tersebut sudah tidak cocok lagi diterapkan pada masa sekarang ini dimana ilmu pengetahuan dan teknologi berkembang pesat.

Samatowa (2010), menyatakan "model belajar yang cocok untuk anak Indonesia adalah belajar melalui pengalaman langsung (learning by doing)". Model pembelajaran adalah pola yang digunakan sebagai pedoman dalam merencanakan pembelajaran di kelompok maupun tutorial (Agus Suprijono, 2011). Fungsi model pembelajaran adalah sebagai pedoman bagi perancang pengajar dan para guru /dosen dalam melaksanakan pembelajaran (Trianto, 2010).

Dosen selama ini lebih banyak memberi ceramah dan latihan mengerjakan soal-soal dengan cepat tanpa memberi pemahaman konsep secara mendalam. Hal ini menyebabkan mahasiswa kurang terlatih untuk mengembangkan daya nalarnya dan mengaplikasikan konsepkonsep yang telah dipelajari dalam kehidupan nyata, sehingga kemampuan berpikir tingkat tinggi mahasiswa kurang dapat berkembang dengan baik. Menurut Bloom dalam Rusyana (2010) berpikir tingkat tinggi adalah berpikir secara logis dan sebagai sesuatu yang masuk akal, berpikir reflektif yang berfokus kepada keputusan mempercayai atau melakukannya.

Rendahnya kemampuan berpikir tingkat tinggi mahasiswa ditunjukkan oleh rendahnya hasil belajar mahasiswa. Maka diperlukan suatu pembelajaran yang dapat mengarahkan mahasiswa untuk mengem- bangkan kemampuan berpikir tingkat tinggi. Oleh karena itu diperlukan suatu strategi yang benar-benar bisa memberi jawaban dari masalah ini. Adapaun strategi pembelajaran yang memenuhi kriteria tersebut adalah pembelajaran berbasis proyek (Project Based Learning) dalam tatanan Group Investigation.

Pembelajaran berbasis proyek adalah pembelajaran dimana tugas-tugas kompleks didasarkan pada pertanyaan yang menantang atau permasalahan yang melibatkan para mahasiswa di dalam desain, pemecahan masalah, pengambilan keputusan, memberi peluang para mahasiswa untuk bekerja secara otonomi dengan periode waktu tertentu, dan akhirnya menghasilkan produk yang nyata atau presentasi (Istarani, 2012).

Hasil penelitian Mahanal (2009) pada siswa SMAN 2 Malang mengemukakan bahwa Project-Based Learning (PjBL) terbukti efektif dalam meningkatkan sikap dan hasil belajar sehingga direkomendasikan untuk diterapkan oleh guru dalam pembelajaran Biologi. Munawaroh (2012), dalam penelitiannya pada siswa kelas VIII reguler SMP N 1 Tambakromo Tahun Pelajaran 2011 /2012, menyatakan bahwa model Project Based Learning dan kooperatif dapat diterapkan untuk membangun empat pilar pembelajaran. Begitu juga dengan penelitian Widiyatmoko dan Pamelasari (2012) pada mahasiswa semester V Prodi Pendidikan IPA FMIPA Universitas Negeri Semarang, mengemukakan melalui pembelajaran berbasis proyek dapat mengembangkan dan menghasilkan alat peraga IPA dengan memanfaatkan bahan bekas pada mata kuliah Produksi Media dan Alat Peraga IPA.

Pembelajaran berbasis proyek memiliki karakteristik adanya kerja kolaboratif dalam kelompok. Proses belajar berkaitan dengan proyek yang mereka kerjakan, mereka juga akan lebih bertanggung jawab 
untuk mengumpulkan material penelitian, data dan informasi untuk proyek mereka (Istarani, 2012).

Cooperative learning menurut Slavin (2010), merujuk pada berbagai macam model pembelajaran dimana para siswa bekerja sama dalam kelompok-kelompok kecil yang terdiri dari berbagai tingkat prestasi, jenis kelamin, dan latar belakang etnik yang berbeda untuk saling membantu satu sama lain dalam mempelajari materi pelajaran. Pembelajaran kooperatif yang tepat untuk dipadukan dengan pembelajaran berbasis proyek pada materi hewan dan lingkungannya adalah pembelajaran kooperatif Group Investigation (GI).

Pembelajaran kooperatif Group Investigation (GI) adalah model pembelajaran dimana mahasiswa dilibatkan sejak perencanaan baik dalam menentukan topik maupun mempelajari melalui investigasi, hal tersebut sejalan dengan pembelajaran berbabis proyek. Model pembelajaran ini dirancang untuk meningkatkan aktivitas mahasiswa dalam mendefinisikan masalah, mengeksplorasi berbagai masalah, mengumpulkan data yang relevan, mengembangkan dan menguji hipotesis. Model pembelajaran ini melatih mahasiswa untuk membangun kemampuan berpikir secara mandiri dan kritis serta melatih mahasiswa dalam menyelesaikan suatu permasalahan dalam kelompok.

Hasil penelitian Eliawati (2011), pada siswa kelas X MAN Gandekan Bantul Tahun Pelajaran 2010 /2011, mengemukakan bahwa penerapan model pembelajaran kooperatif Group Investigation efektif dalam peningkatan partisipasi dan prestasi belajar siswa pada materi pokok jamur kelas $\mathrm{X}$ MAN Gandekan Bantul Tahun Pelajaran $2010 / 2011$.

Dari hasil pengamatan selama satu semester, proses pembelajaran yang terjadi hanya menekankan pada aspek pengetahuan dan pemahaman, sedangkan aspek aplikasi, analisis, evaluasi bahkan kreasi, sangat jarang sekali dilakukan oleh tim pengajar. Berdasarkan masalahmasalah yang ditemukan peneliti di USI Pematangsiantar, maka peneliti memilih melakukan penelitian di Universitas tersebut.

Mengacu pada masalah pembelajaran dalam perkuliahan ekologi hewan yang dialami mahasiswa Universitas Simalungun Pematangsiantar, pembela-jaran berbasis proyek dalam tatanan pembelajaran Group Investigation memang penting dan dapat mengatasi persoalan rendahnya berpikir tingkat tinggi mahasiswa. Untuk itu perlu dilakukan penelitian tentang pengaruh model pembelajaran berbasis proyek dalam tatanan pembelajaran Group Investigation pada matakuliah ekologi hewan terhadap berpikir tingkat tinggi mahasiswa Universitas Simalungun (USI) Pematangsiantar.

\section{METODE PENELITIAN}

Penelitian ini dilaksanakan di Program Studi Pendidikan Biologi FKIP Universitas Simalungun, Jalan Sisingamangaraja Barat 1, Bah Kapul, Kecamatan Siantar Martoba, Pematangsiantar pada bulan Desember 2014 sampai Maret 2015.

Sampel dalam penelitian ini diambil secara total sampling yaitu semua mahasiswa semester VI Program Studi Pendidikan Biologi Universitas Simalungun Pematangsiantar dengan jumlah 60 orang yang terdiri dari tiga kelas, dengan perincian kelompok eksperimen yang dibelajarkan dengan model pembelajaran berbasis proyek dalam tatanan Group Investigation yakni kelas IIIA yang berjumlah 20 orang, kelompok eksperimen yang dibelajarkan dengan model 
pembelajaran Group Investigation yakni kelas IIIB yang berjumlah 20 orang, dan kelompok kontrol yang dibelajarkan dengan model pembelajaran konvensional yakni kelas IIIC yang berjumlah 20 orang.

Penelitian yang akan dilakukan menggunakan metode eksperimental semu (quasi eksperiment). Desain penelitian yang akan digunakan adalah nonequivalent control group design atau non randomized control pretest postest design, artinya kelompok eksperimen maupun kelompok kontrol tidak dipilih secara random. Dalam desain ini, baik kelompok eksperimental maupun kelompok kontrol dibandingkan, kemudian kelompok yang ada diberi pretes, selanjutnya diberikan perlakuan, dan terakhir diberikan postes.

Tabel 1. Desain Penelitian

\begin{tabular}{ccc}
\hline Pretes & Treatmen & Postes \\
\hline $\mathrm{T}_{1}(\mathrm{~A})$ & $\mathrm{X}(\mathrm{A})$ & $\mathrm{T}_{2}(\mathrm{~A})$ \\
$\mathrm{T}_{1}(\mathrm{~B})$ & $\mathrm{X}(\mathrm{B})$ & $\mathrm{T}_{2}(\mathrm{~B})$ \\
$\mathrm{T}_{1}(\mathrm{C})$ & $\mathrm{X}(\mathrm{C})$ & $\mathrm{T}_{2}(\mathrm{C})$ \\
\hline
\end{tabular}

Untuk memenuhi persyaratan kesahihan data yang diperoleh melalui penelitian ini, dilakukan pengendalian validitas internal dan eksternal. Teknik pengumpulan data dilakukan melalui uji pretes dan uji postes. Instrumen pengumpulan data terdiri dari alat tes tertulis untuk mengetahui tingkat keberhasilan belajar ekologi hewan yang dalam hal ini dibatasi pada berpikir tingkat tinggi mahasiswa.

Instrumen berpikir tingkat tinggi atau hasil belajar tingkat tinggi disusun dalam bentuk essay tes sebanyak 6 item pada aspek kognitif Taksonomi Bloom terdiri atas aspek analisis (C4), evaluasi (C5) dan kreasi (C6). Setiap jawaban yang benar diberi skor 5 sedangkan yang salah diberi skor 0 . Tes hasil belajar mahasiswa yang digunakan untuk mengukur hasil belajar kognitif siswa terlebih dahulu diujicobakan untuk mengetahui validitas, reliabilitas, daya beda dan tingkat kesukarannya. Pengujian validitas dan reliabilitas instrumen tes hasil belajar mahasiswa dilakukan dengan bantuan program komputer Mikrosoft Excel. Begitu juga untuk uji daya beda dan tingkat kesukaran tes dilakukan dengan bantuan program komputer Mikrosoft Excel.
Penelitian ini menggunakan teknik analisis data berupa analisis deskriptif dan analisis inferensial. Analisis deskriptif dimaksudkan untuk mendeskripsikan data penelitian meliputi mean, median, standart deviasi dan kecenderungan data. Analisis statistik inferensial dilakukan untuk menguji hipotesis penelitian, yang terlebih dahulu dilakukan uji prasyarat terhadap data yang dikumpulkan dengan menggunakan uji normalitas dan homogenitas.

Teknik analisis data inferensial digunakan untuk menguji hipotesis penelitian dengan menggunakan uji $\mathrm{F}$ ANAKOVA pada taraf signifikan $\alpha=5 \%$ kemudian dilanjut dengan Post-Hoc Test (uji lanjut) dengan teknik Tukey. Uji lanjut dilakukan untuk mengetahui variabel manakah yang memiliki perbedaan yang signifikan. Untuk menguji normalitas data digunakan uji Kolmogorof-Smirnov pada taraf signifikan 5\%. Uji homogenitas varians data menggunakan Levene Test pada taraf signifikan 5\%. Data dianalisis dengan menggunakan software SPSS 21.0. 


\section{HASIL DAN PEMBAHASAN}

Deskripsi data yang disajikan dalam penelitian ini menunjukkan bahwa hasil pretes kelas pembelajaran berbasis proyek dalam tatanan Group Investigation diperoleh nilai tertinggi sebesar 50 dan nilai terendah 33 dengan rata-rata dan standard deviasi $(41,6 \pm 4,78)$ dan dari hasil uji normalitas dengan menggunakan uji Kolmogorov Smirnov disimpulkan bahwa data kemampuan awal siswa kelas pembelajaran berbasis proyek dalam tatanan Group Investigation memiliki sebaran data yang berdistribusi normal $(\mathrm{Z}=0,827 ; \mathrm{P}=0,501)$. Pada kelas Group Investigation, hasil pretes siswa diperoleh nilai tertinggi 50 dan terendah 30 dengan rata-rata nilai dan standard deviasi $(42,30 \pm 5,72)$ serta data kemampuan awal siswa kelas Group Investigation memiliki sebaran data yang berdistribusi normal $(\mathrm{Z}=0,677 ; \mathrm{P}=0,750)$. Sementara pada kelas konvensional dari hasil pretes diperoleh nilai tertinggi 47 dan terendah 33 dengan rata-rata nilai dan standard deviasi $(40,6 \pm 4,68)$ serta memiliki sebaran data berdistribusi normal $(\mathrm{Z}=0,800 ; \mathrm{P}=0,544)$.
Selanjutnya hasil postes setelah dibelajarkan dengan pembelajaran berbasis proyek dalam tatanan Group Investigation diperoleh nilai tertinggi sebesar 93 dan terendah 83 dengan rata-rata dan nilai dan standard deviasi $(88,60 \pm 3,73)$ serta memiliki sebaran data berdistribusi normal $(\mathrm{Z}=0,808 ; \mathrm{P}=0,531)$. Pada kelas Group Investigation, dari hasil postes yang diperoleh nilai tertinggi sebesar 87 dan terendah 77 serta rata-rata nilai dan standart deviasi $(81,00 \pm 4,01)$ serta memiliki sebaran data yang berdistribusi normal $(Z=1,111 ; P=0,169)$. Pada kelas yang dibelajarkan dengan pembelajaran konvensional, dari hasil postes diperoleh nilai tertinggi 80 dan terendah 70 serta ratarata nilai dan standard deviasi (74,60 \pm $3,58)$ serta memiliki sebaran data $(Z=1,21$; $\mathrm{P}=0,10)$. Selanjutnya hasil uji homogenitas data berpikir tingkat tinggi mahasiswa dengan menggunakan uji Levene's Test menunjukkan variasi data antara ketiga kelompok sampel dalam populasi adalah homogen $(\mathrm{F}=0,122 ; \mathrm{P}=0,886)$. Deskripsi berpikir tingkat tinggi mahasiswa dapat dilihat pada tabel 2.

Tabel 2. Deskripsi Berpikir Tingkat Tinggi Mahasiswa

\begin{tabular}{lcccccc}
\hline \multirow{2}{*}{ Statistik } & \multicolumn{3}{c}{ Pretes } & \multicolumn{3}{c}{ Postes } \\
\cline { 2 - 7 } & PJBL_GI & GI & KONV & PJBL_GI & GI & KONV \\
\hline Mean & 41,60 & 42,30 & 40,60 & 88,60 & 81,00 & 74,60 \\
Std. Dev & 4,78 & 5,72 & 4,68 & 3,73 & 4,01 & 3,59 \\
N. Max & 50,00 & 53,00 & 47,00 & 93,00 & 87,00 & 80,00 \\
N. Min & 33,00 & 30,00 & 33,00 & 83,00 & 77,00 & 70,00 \\
\hline
\end{tabular}

Berdasarkan hasil uji hipotesis diperoleh bahwa berpikir tingkat tinggi mahasiswa yang dibelajarkan dengan model pembelajaran berbasis proyek dalam tatanan Group Investigation diperoleh $\mathrm{F}_{\text {hitung }}$ $>\mathrm{F}_{\text {tabel }}$ yaitu $67,742>3,15$ serta nilai probabilitas $0,000<0,001$ menunjukkan bahwa model pembelajaran secara signifikan berpengaruh terhadap berpikir tingkat tinggi mahasiswa. Selanjutnya hasil uji Tukey menunjukkan bahwa berpikir tingkat tinggi mahasiswa yang dibelajarkan dengan pembelajaran berbasis proyek dalam tatanan Group Investigation (88,60 \pm 3,73 ) secara signifikan lebih tinggi dibandingkan dengan berpikir tingkat tinggi mahasiswa yang dibelajarkan dengan model pembelajaran Group Investigation 
tanpa PjBL $(81,00 \pm 4,01)$ maupun yang dibelajarkan dengan pembelajaran konvensional (74,60 $\pm 3,58)$. Pengaruh model pembelajaran berbasis proyek dalam tatanan Group Investigation (GI) terhadap berpikir tingkat tinggi mahasiswa USI Pematangsiantar tersaji pada Gambar 1.

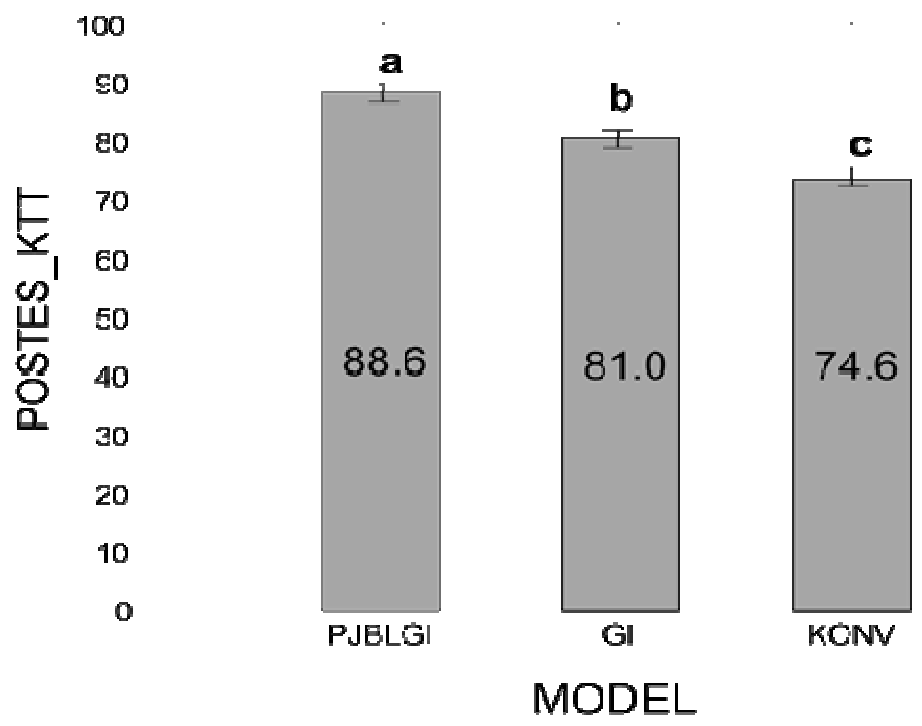

Gambar 1. Pengaruh model pembelajaran berbasis proyek dalam tatanan Group Investigation, pembelajaran Group Investigation, dan pembelajaran konvensional pada matakuliah ekologi hewan terhadap berpikir tingkat tinggi mahasiswa USI Pematangsiantar $(\mathrm{F}=67,742 ; \mathrm{P}=0,000)$. Huruf yang berbeda di atas diagram berarti berbeda signifikan (uji Tukey).

Pada hasil penelitian ini diperoleh bahwa kemapuan berpikir tingkat tinggi mahasiswa yang dibelajarkan dengan model pembelajaran berbasis proyek dalam tatanan Group Investigation memberikan pengaruh sebesar 9\% lebih tinggi dibandingkan dengan pembelajaran Group Investigation tanpa pembelajaran berbasis proyek dan 18\% lebih tinggi dibandingkan dengan pembelajaran konvensional. Model pembelajaran Group Investigation memberikan pengaruh sebesar $8,5 \%$ lebih tinggi dibandingkan pembelajaran konvensional. Berdasarkan hasil analisis data penelitian diperoleh $\mathrm{F}_{\text {hitung }}>\mathrm{F}_{\text {tabel }}$ dengan demikian $\mathrm{H}_{0}$ ditolak dan $\mathrm{H}_{\mathrm{a}}$ diterima sehingga disimpulkan ada pengaruh yang signifikan antara penggunaan model pembelajaran berbasis proyek dalam tatanan Group Investigation, pembelajaran Group Investigation, dan pembelajaran konvensional terhadap berpikir tingkat tinggi pada matakuliah ekologi hewan mahasiswa USI Pematangsiantar.

Hal ini menunjukkan bahwa model pembelajaran berbasis proyek dalam tatanan Group Investigation tebukti efektif dapat meningkatkan berpikir tingkat tinggi mahasiswa. Hal ini dikarenakan pada model pembelajaran berbasis proyek dalam tatanan Group Investigation mahasiswa dituntut untuk dapat merencanakan, menginvestigasi, mengerjakan proyek, sampai mempresentasikan hasil proyek mereka pada matakuliah ekologi hewan yang membahas tentang hewan dan lingkungannya. Setiap tahapan kegiatan tersebut diperoleh mahasiswa dengan 
menggunakan pendekatan berpikir secara ilmiah.

Sebagaimana dikemukakan oleh Sanjaya (2006), bahwa pembelajaran berbasis proyek (PjBL) merupakan rangkaian aktivitas pembelajaran yang menekankan kepada proses penyelesaian tugas-tugas kompleks yang dihadapi secara ilmiah. Dengan model pembelajaran berbasis proyek dalam tatanan Group Investigation mahasiswa dapat meningkatkan hasil belajarnya khususnya kemampuan berpikir tingkat tingginya, dimana mahasiswa dilatih dalam merencanakan, menginvestigasi, mengerjakan proyek, sampai mempresentasikan hasil proyek, untuk tercapainya tujuan pembelajaran dari mata kuliah ekologi hewan itu sendiri dan lebih memahami isi materi yang dipelajari yaitu mengenai hewan dan lingkungannya.

Pendapat senada juga dikemukakan oleh Boonde (2011) pada mahasiswa Sekolah Tinggi Teknik di Thailand, menyimpulkan bahwa Model Pembelajaran Berbasis Proyek dapat membantu meningkatkan keterampilan pembelajaran kooperatif siswa yang berguna untuk kehidupan sehari-hari dan pekerjaan mereka setelah kelulusan. Hasil penelitian Marlinda (2012) pada siswa pada kelas VII SMP Dwijendara Denpasar tahun pelajaran 2011 /2012, menyatakan bahwa pembelajaran berbasis proyek dapat digunakan sebagai salah satu alternatif fasilitas belajar siswa dalam rangka mengoptimalkan kemampuan berpikir kreatif dan kinerja ilmiah siswa dalam belajar.

Selanjutnya Slavin (2010), menyatakan bahwa model pembelajaran kooperatif Group Investigation dikembangkan untuk mencapai hasil belajar berupa prestasi akademik, toleransi, menerima keragaman, dan pengembangan keterampilan sosial. Hasil penelitian ini juga sesuai dengan hasil penelitian Eliawati (2011) pada siswa kelas X MAN Gandekan Bantul Tahun Pelajaran 2010 /2011, mengemukakan bahwa penerapan model pembelajaran kooperatif Group Investigation efektif dalam meningkatkan partisipasi dan prestasi belajar siswa pada materi pokok jamur kelas X MAN Gandekan Bantul Tahun Pelajaran 2010 /2011. Karena, penggunaan strategi pembelajaran ini akan mempermudah peserta didik dalam memahami dan mengingat kembali materi yang telah dipelajari.

(Sudewi, et al 2014) juga menyatakan bahwa model pembelajaran yang dapat mengaitkan pengalaman dalam kehidupan nyata peserta didik dengan materi pelajaran sains terutama Biologi serta dapat merangsang dan melatih keterampilan berpikir tingkat tinggi peserta didik dari aspek terendah sampai aspek tertinggi taksonomi Bloom adalah model pembelajaran kooperatif tipe Group Investigation (GI).

Kemampuan berpikir tingkat tinggi mahasiswa pada matakuliah ekologi hewan dengan menggunakan model pembelajaran berbasis proyek dalam tatanan Group Investigation ini lebih tinggi dibandingkan dengan menggunakan model pembelajaran konvensional. Hal ini dikarenakan pada model pembelajaran tersebut merupakan model pembelajaran yang inovatif dan lebih menekankan pada belajar kontekstual melalui kegiatan-kegiatan yang kompleks. $\mathrm{Hal}$ ini dibuktikan dengan observasi pembelajaran yang melibatkan seluruh mahasiswa untuk berpikir tentang hewan dan lingkungannya pada matakuliah ekologi hewan.

Untuk mengetahui keberhasilan suatu pembelajaran yang terkait dengan kemampuan berpikir tingkat tinggi maka perlu dilakukan pengukuran (evaluasi) terhadap pembelajaran tersebut. Steven dalam Martomidjoyo (2009) mengutarakan 
bahwa berpikir tingkat tinggi adalah metode tentang penyelidikan ilmiah, yaitu: mengidentifikasikan masalah, merumuskan hipotesis, mencari dan mengumpulkan data-data yang relevan, menguji hipotesis secara logis dan evaluasi serta membuat kesimpulan yang reliabel.

Dengan demikian, berdasarkan hasil penelitian, pengujian statistik dan teoriteori yang ada serta berdasarkan hasil penelitian yang telah dipublikasikan dengan tema yang sama, terbukti bahwa model pembelajaran berbasis proyek dalam tatanan Group Investigation memberikan pengaruh yang lebih baik terhadap hasil belajar siswa. Dalam penelitian ini khususnya mampu mengasah kemampuan berpikir tingkat tinggi mahasiswa karena pada dasarnya pembelajaran tersebut menuntut mahasiswa untuk dapat berkolaborasi dengan kelompok dalam berinvestigasi mengenai tema yang akan mereka kerjakan hingga menghasilkan suatu produk yang nyata sehingga berpikir tingkat tinggi mahasiswa dapat berkembang dengan baik. Sedangkan kelompok mahasiswa yang dibelajarkan dengan pembelajaran konvensional, proses pembelajaran cenderung berpusat pada dosen dengan menggunakan metode ceramah. Selama proses pembelajaran, berpikir tinggi mahasiswa kurang diasah, karena siswa lebih banyak belajar secara individual dengan menerima, mencatat, dan menghafal materi pelajaran yang diterimanya dari dosen sebagai penentu jalannya proses pembelajaran.

\section{SIMPULAN}

Berdasarkan hasil dan pembahasan penelitian yang telah diuraikan diatas, maka dapat disimpulkan sebagai berikut: Terdapat pengaruh yang signifikan berpikir tingkat tinggi mahasiswa yang dibelajarkan dengan pembelajaran berbasis proyek dalam tatanan Group Investigation dan pembelajaran konvensional pada mata kuliah ekologi hewan di Universitas Simalungun Pematangsiantar Tahun Pelajaran $2014 \quad / 2015 . \quad$ Model pembelajaran yang lebih baik dan lebih tinggi pengaruhnya adalah model pembelajaran berbasis proyek dalam tatanan Group Investigation.

\section{REFERENSI}

Boondee, V., Kidrakarn. \& Sa-Ngiamvibool (2011). A Learning and Teaching Model using Project-Based Learning (PBL) on the $\mathrm{Web}$ to Promote Cooperative Learning. European Journal of Social Sciences. 21 (3): 498-507.

Dimyati \& Mudjiono (2006). Belajar dan Pembelajaran. Jakarta: Rineka Cipta.

Eliawati (2011). Efektifitas Penerapan Model Pembelajaran Kooperatif Tipe STAD Terhadap Partisipasi dan Prestasi Belajar pada Materi Pokok Jamur Siswa Kelas X di MAN Gandekan Bantul Tahun Ajaran 2010 /2011. Skripsi. Yogyakarta: Universitas Islam Negeri Sunan Kalijaga.

Istarani (2012). 50 Model Pembelajaran Inovatif. Medan: Media Persada.

Mahanal, S., Darmawan, E., Corebima, A.D., Zubaidah, S (2009). Pengaruh Pembelajaran Project Based Learning (PjBL) pada Materi Ekosistem Terhadap Sikap dan Hasil Belajar Siswa SMAN 2 Malang. Universitas Negeri Malang.

Marlinda, M (2012). Pengaruh Pembelajaran Berbasis Proyek Terhadap Kemampuan Berpikir Kreatif dan Kinerja Ilmiah Siswa. Jurnal Penelitian Pascasarjana UNDIKSHA. (Vol 2, No 2 Tahun 2012).

Martomidjoyo, R (2009). Berpikir Kritis dalam Pembelajaran Sains. Tersedia pada:http://russamsimartomidjojocentre.bl ogspot.com/2009/05/keterampilan-prosessains.html, diakses pada tanggal 03 Desember 2014.

Munawaroh, R., Subali. \& Sopyan (2012). Penerapan Model Project Based Learning dan Kooperatif untuk Membangun Empat Pilar Pembelajarn Siswa SMP. Unnes Physics Education Journal (UPEJ). 1 (1): 33-37. 
Rusyana, A \& Setiawan, I (2010). Prinsip-prinsip Pembelajaran Efektif. Jakarta: Trans Mandiri Abadi.

Samatowa, U (2010). Bagaimana Pembelajaran IPA di Sekolah Dasar. Jakarta: Depdiknas.

Sanjaya, W (2006). Strategi Pembelajaran Berorientasi Standart Proses Pendidikan. Jakarta: Kencana Prenada Media Group.

Slavin, R.E (2010). Cooperative Learning. Bandung: Nusa Media.

Sudewi,Ni.L.,Saubagia,I.W.,Tika,I.N.(2014). Studi Komparasi Penggunaan Model Pembelajaran Problem Based Learning (PBL) dan Kooperatif Tipe Group
Investigation (GI) Terhadap Hasil Belajar Berdasarkan Taksonomi Bloom. e-Journal Program Pascasarjana Universitas Pendidikan Ganesha Program Studi IPA (Volume 4 Tahun 2014).

Trianto (2010). Belajar dan Faktor-Faktor yang Mempengaruhinya. Jakarta: Rineka Cipta.

Widiyatmoko, A. \& Pamelasari, S.D (2012).

Pembelajaran Berbasis Proyek untuk Mengembangkan Alat Peraga IPA dengan Memanfaatkan Bahan Bekas Pakai. Jurnal Pendidikan IPA Indonesia (JPII). 1(1): 51-56. 